\title{
KAPASITAS ANTIOKSIDAN SERTA INHIBISI LIPASE DAN KOLESTEROL ESTERASE DARI BUBUK SARI BUAH PAMELO CITRUS MAXIMA KULTIVAR NAMBANGAN SECARA IN VITRO
}

\section{Antioxidant Capacity and In Vitro Inhibition of Lipase and Cholesterol Esterase by Citrus maxima Cultivar Nambangan Juice Powder}

\author{
Setyaning Pawestri, Endang Prangdimurti*, Nur Wulandari \\ Departemen Ilmu Teknologi Pangan - Fakultas Teknologi Pertanian - Institut Pertanian Bogor \\ Jl. Lingkar Akademik - Bogor 16002 \\ *Penulis Korespondensi, email : prangdimurti@apps.ipb.ac.id
}

\begin{abstract}
ABSTRAK
Jeruk pamelo (Citrus maxima) kultivar Nambangan kaya akan senyawa bioaktif, seperti asam askorbat dan senyawa fenolik (flavonoid, narirutin, naringin, dan neohesperidin). Penelitian terdahulu menemukan bahwa berbagai spesies pamelo menurunkan kadar LDL-c, trigliserida dan kolesterol pada tikus hiperkolesterolemia. Namun, meski memiliki nilai fungsional dan manfaat kesehatan yang tinggi, tingkat konsumsi pamelo masih rendah, kemungkinan karena rasanya yang pahit dan asam. Produk bubuk menjadi solusi masalah ini dan juga dapat dimanfaatkan dalam berbagai aplikasi. Bubuk sari buah lebih praktis dan stabil untuk digunakan. Namun demikian, proses yang digunakan untuk memperoleh serbuk harus mempertimbangkan kandungan senyawa bioaktif. Bubuk sari buah diperoleh dengan pengeringan semprot dengan penambahan bahan penyalut (maltodekstrin/MD DE12 dan gum arab/GA) dari empat formulasi (10: 0, 9: 1, 8: 2, dan 7: 3 MD/GA) dengan konsentrasi dari 15\% $\mathrm{w} / \mathrm{v}$ jus. Penelitian ini bertujuan untuk mengetahui pengaruh perbedaan rasio bahan penyalut (MD/GA) terhadap senyawa bioaktif sari buah pamelo dan menilai potensi hipolipidemik secara in vitro dalam menghambat lipase pankreas dan kolesterol esterase. Hasil penelitian menunjukkan bahwa aktivitas DPPH, total fenolik, total flavonoid, dan asam askorbat tertinggi ditunjukkan oleh ekstrak bubuk MD/GA 7:3. Nilai IC $_{50}$ ekstrak 4 bubuk jus buah pamelo terhadap lipase dan kolesterol esterase berkisar antara 211,42-308,40 $\mu \mathrm{g} / \mathrm{ml}$, dan 934,19-1352,05 $\mu \mathrm{g} / \mathrm{ml}$. Nilai $\mathrm{IC}_{50}$ terendah diperoleh dari ekstrak bubuk MD/GA 7:3. Ekstrak bubuk sari buah pamelo menunjukkan efek yang lebih kuat dalam menghambat aktivitas lipase pankreas daripada menghambat kolesterol esterase.
\end{abstract}

Kata kunci: Enkapsulasi; Kapasitas Antiokidan; Kolesterol Esterase; Lipase Pankreatik; Pamelo

\section{ABSTRACT}

Pummelo (Citrus maxima) cultivar Nambangan is rich in bioactive compounds, such as ascorbic acid and phenolic compounds (flavonoids, narirutin, naringin, and neohesperidin). Previous studies showed that various species of pummelo lower LDL-c, triglyceride and cholesterol levels in hypercholesterolemic rats. However, despite its high functional value and health benefit, the consumption level of pummelo is relatively low, probably due to its bitter taste and astringency. Powdered product can overcome this problem and be applied for various applications. Powdered fruit juice is more practical and stable to utilize. However, the process used in obtaining powder should consider the bioactive compounds content. Pummelo powders were obtained by spray drying with addition of coating agents (maltodextrin/MD DE12 and gum arabic/GA) of four formulations (10:0, 9:1, 8:2, and 7:3 MD/GA) with the concentration of $15 \% \mathrm{w} / \mathrm{v}$ juice. This study aimed to determine the effect of the difference ratios 
Jurnal Teknologi Pertanian Vol. 22 No. 3 [Desember 2021] 149-160

Kapasitas Antioksidan serta Inhibisi Lipase dan Kolesterol Esterase dari BubukSari Buah Pamelo [Pawestri dkk]

of coating agent $(M D / G A)$ on bioactive compounds of pummelo juice powder and assess the hypolipidemic in vitro potential in inhibiting pancreatic lipase and cholesterol esterase. The results showed that the highest DPPH scavenging activity, total phenolic, total flavonoid, and ascorbic acid were shown by the extract of 7:3 MD/GA powder. The $I C_{50}$ values of an extract of 4 pummelo powders against lipase and cholesterol esterase was ranging from 211.42 - $308.40 \mu \mathrm{g} / \mathrm{ml}$, and 934.19 - $1352.05 \mu \mathrm{g} / \mathrm{ml}$, respectively. The lowest $I C_{50}$ values were obtained by the extract of 7:3 MD/GA powder. The extracts of pummelo powders showed stronger effect in inhibiting pancreatic lipase activity than inhibiting cholesterol esterase.

Keywords : Antioxidant Capacity, Cholesterol Esterase, Encapsulation, Pancreatic Lipase, Pummelo

\section{PENDAHULUAN}

Kultivar pamelo (Citrus maxima) Nambangan merupakan jenis kultivar asli Indonesia yang dibudidayakan di Magetan, Jawa Timur. Kultivar ini dikenal karena ukurannya yang besar dan ketahanannya terhadap CVPD (Citrus Vein Ploem Degeneration) (Susanto, 2004). Komponen utama dalam jeruk pamelo adalah flavanon, narirutin, eriocitrin, naringin, dan neohesperidin. Beberapa penelitian terdahulu telah mendeteksi keberadaan flavanon seperti hesperidin, neoriositrin, flavon (roifolin dan diosmin), flavanon aglikon (naringenin, taksifolin, dan hesperitin), serta polimetoksiflavon (nobiletin dan tangeretin) (Kawaii et al., 1999; Tripoli et al., 2007; Xu et al., 2008; Zhang et al., 2011). Sifat antioksidan pada jeruk pamelo bermanfaat untuk meningkatkan kesehatan tubuh. Penelitian secara in vivo menunjukkan bahwa sari buah jeruk pamelo dampak positif pada tikus hiperkolesterolemia. Suplementasi naringin menurunkan plasma lipid pada tikus yang diberi diet kolesterol tinggi, dan naringin dosis $0,2 \mathrm{~g} / \mathrm{kg}$ pakan menghambat jalur sintesis asam lemak bebas ( $\mathrm{Pu}$ et al., 2012). Sari buah C. maxima menghambat aktivitas ACE (angiotensin 1converting enzyme), menurunkan trigliserida dan kolesterol, dan LDL-c serta meningkatkan HDL-c pada tikus hiperkolesterolemia (Oboh et al., 2014).

Meskipun jeruk pamelo telah dikenal manfaat kesehatan dan kandungan gizinya, tetapi konsumsi pamelo masih rendah, kemungkinan karena rasa pahit dan asam yang menyebabkan pamelo tidak disukai konsumen (Chen et al., 2015). Jeruk pamelo merupakan buah musiman dengan umur simpan terbatas pada suhu ruang. Selain itu buah ini mudah rusak karena kandungan airnya yang tinggi yang dapat memicu pertumbuhan mikroba dan menurunkan kualitas (Garofulic et al., 2016). Oleh karena itu, mendapatkan produk kering dengan menggunakan proses enkapsulasi dapat mengatasi masalah tersebut.

Pengeringan semprot adalah proses yang direkomendasikan untuk mengubah sari buah menjadi bubuk. Bubuk memiliki stabilitas yang lebih tinggi dan umur simpan yang lebih lama dibanding buah dan mudah didistribusikan (Agudelo et al., 2017). Selain itu, bubuk sari buah memiliki berbagai potensi aplikasi dalam industri pangan, sebagai produk setengah jadi atau produk jadi dengan nilai gizi dan fungsional yang tinggi (Garofulic et al., 2016). Pemilihan bahan penyalut merupakan langkah penting dalam pengeringan semprot karena mempengaruhi karakteristik dan stabilitas produk akhir (Yousefi et al., 2011). Bahan penyalut harus mampu melindungi bahan aktif dari perubahan yang disebabkan oleh oksidasi atau interaksi kimiawi (Botrel et al., 2012). Dengan demikian, senyawa bioaktif dan kapasitas antioksidan produk kering dapat dipertahankan (Agudelo et al., 2017; Fang dan Bhandari, 2012).

Maltodekstrin merupakan bahan penyalut yang paling umum digunakan karena kemampuannya dalam meningkatkan stabilitas komponen yang peka panas, mudah diperoleh, dan murah (Kha et al., 2010). Selain itu, maltodekstrin memiliki aroma dan rasa netral, viskositas rendah, dan dapat melindungi komponen dari oksidasi. Keterbatasan maltodekstrin yakni kemampuan emulsi yang rendah dan retensi senyawa volatil yang rendah 
sehingga diperlukan pencampuran dengan jenis bahan penyalut lainnya (Fernandes et al., 2014). Gum arab dikenal sebagai bahan penyalut dengan kemampuan emulsifikasi tinggi, memiliki kelarutan yang tinggi dan viskositas yang rendah pada konsentrasi tinggi (Atefi et al., 2017). Namun, penggunaan gum arab untuk enkapsulasi terkendala harga yang mahal dan pasokan yang terbatas (Krishnan et al., 2005).

Beberapa penelitian telah mengeksplorasi pemanfaatan bahan penyalut untuk melindungi senyawa sensitif seperti asam askorbat (Al-Ismail et al., 2016; PalmaRodrígueza et al., 2018), antosianin (Betz dan Kulozik, 2011), likopen (Rocha et al., 2012), dan betalain (Pitalua et al., 2010; Ravichandran et al., 2014). Kombinasi maltodekstrin $(60 \%)$ dan gum arab $(40 \%)$ telah digunakan untuk mengenkapsulasi prosianidin dari biji anggur, selama tahap kritis pengeringan, pengamatan menunjukkan tidak ada perubahan prosianidin dan stabilitasnya meningkat (Zhang et al., 2007). Agudelo et al. (2017) meneliti pengaruh perbedaan bahan penyalut dan bermacam kombinasi konsentrasi pada polifenol dan flavonoid pamelo. Hasil penelitian menunjukkan bahwa bubuk pamelo yang dienkapsulasi gum arab dan serat bambu (4:2) memberikan nilai flavonoid dan polifenol yang lebih tinggi daripada bubuk pamelo yang dienkapsulasi gum arab dan serat bambu (4:0).

Pemilihan bahan penyalut dan konsentrasi yang tepat diperlukan untuk menghasilkan bubuk sari buah yang memiliki nilai gizi dan fungsional yang tinggi (Garofulic et al., 2016). Penelitian ini menggunakan kombinasi formulasi bahan penyalut (maltodekstrin dan gum arab) untuk menghasilkan bubuk sari buah pamelo.

Penelitian ini bertujuan untuk mengevaluasi pengaruh kombinasi formulasi bahan penyalut dalam bubuk sari buah pamelo terhadap kapasitas antioksidan, total fenol, total flavonoid, dan asam askorbat serta menilai potensi hipolipidemik secara in vitro bubuk sari buah dalam menghambat aktivitas lipase pankreas dan kolesterol esterase.

\section{METODE}

Peralatan untuk pembuatan bubuk sari buah pamelo adalah spray dryer (Buchi 190 Mini), sentrifus (IEC Centra MP4R centrifuge), homogenizer (Silverson L4R, Armfield), dan rotary evaporator (Buchi Rotavapor R-300). Alat untuk analisis antioksidan dan inhibisi enzim adalah mikropipet (DragonLab, Fin Pippete), microplate absorbance reader (iMarkTM, BioRad dan Epoch Biotech), dan 96-well microplates (Biologix). Bahan utama penelitian ini adalah Jeruk pamelo (C. maxima) kultivar Nambangan usia 4-5 bulan dengan berat 1,5-2,0 $\mathrm{kg}$ diperoleh dari perkebunan di Desa Tamanan (Kabupaten Magetan, Jawa Timur, Indonesia), maltodekstrin DE12, dan gum arab dari Pervetti Van Melle (Jakarta, Indonesia).

Bahan kimia yang digunakan untuk analisis adalah 2,2-difenil-1-pikrilhidrazil (DPPH), 2,6-dichlorophenolindophenol (DCIP), reagen Folin-Ciocalteau, $\mathrm{Na}_{2} \mathrm{CO}_{3}$, $\mathrm{AlCl}_{3}, \mathrm{CH}_{3} \mathrm{COOK}, \mathrm{HPO}_{3}$, asam askorbat, kuersetin, asam galat, kolesterol esterase pankreas C9464 ( $\geqslant 15.000$ unit/g protein) (Sigma Aldrich), lipase pankreatik L3126 (tipe II, 100-500 unit/mg protein) (Sigma Aldrich), garam natrium asam taurocholic (Sigma Aldrich), 4-nitrofenil butirat (pNPB) (Sigma Aldrich), Triton-X-100 (Sigma Aldrich), PBS, $\mathrm{NaCl}$, DMSO (Merck), orlistat (Roche), dan simvastatin (Bernofarm).

Penelitian yang dilakukan dibagi menjadi 3 tahap, yaitu pembuatan bubuk sari buah pamelo, analisis aktivitas antioksidan dan analisis potensi hipolipidemik secara in vitro. Pembuatan bubuk sari buah pamelo terdiri dari pembuatan konsentrat sari buah, pembuatan bubuk sari buah dengan penyemprotan kering dan ekstraksi bubuk. Analisis aktivitas antioksidan meliputi aktivitas DPPH, uji asam askorbat, uji total fenolik, dan uji total flavonoid. Sedangkan analisis potensi hipolipidemik secara in vitro adalah pengukuran daya hambat lipase pankreas dan kolesterol esterase pankreas oleh ekstrak bubuk sari buah pamelo. 


\section{Pembuatan bubuk sari buah pamelo Preparasi konsentrat sari buah}

Jeruk pamelo dikupas dari kulit luar kemudian kulit ari dari tiap segmen dikupas, daging buah ditimbang berat awalnya. Daging buah dijadikan sari buah dengan hidrolic presser (Muzaffar et al., 2016). Sari buah disaring dengan 100 mesh nilon guna memisahkannya dari sisa kulit ari sehingga menghindari gangguan terhadap atomizer (Kha et al., 2010). Sari buah diukur kandungan padatan terlarut (TSS) dengan refraktometer. Sari buah dipekatkan menggunakan rotary evaporator (Buchi Rotavapor R-300) pada suhu $70{ }^{\circ} \mathrm{C}$ hingga mencapai 11-12 ${ }^{\circ} \mathrm{Bx}$ (Mishra et al., 2014) selama \pm 15 menit hingga volume berkurang menjadi $\pm 500 \mathrm{ml}$ untuk mendapatkan 11 - 12 oBx (Garofulic et al., 2016).

\section{Produksi bubuk sari buah pamelo}

Empat formulasi kombinasi bahan penyalut digunakan dalam proses pengeringan semprot, formulasi ini didasarkan pada penelitian Cynthia et al. (2015) (Tabel 1). Konsentrasi bahan penyalut $15 \%$ (w/v) ditambahkan ke sari buah, konsentrasi ini dipilih sesuai dengan penelitian terdahulu (Kha et al., 2010). Campuran tersebut kemudian dihomogenisasi menggunakan homogenizer (Silverson L4R, Armfield) pada $5000 \mathrm{rpm}$ selama 5 menit (Angel et al., 2009).

Pengeringan semprot dengan mesin pengering semprot (Buchi 190) dilakukan pada suhu inlet $160 \pm 3{ }^{\circ} \mathrm{C}$ dan suhu outlet 80 $\pm 3{ }^{\circ} \mathrm{C}$ (Di Battista et al., 2015). Setelah pengeringan semprot selesai, dan suhu inlet menurun di bawah 50 o $\mathrm{C}$, bubuk dikumpulkan dalam kemasan polietilen gelap untuk melindunginya dari paparan cahaya dan mencegah oksidasi. Serbuk ditimbang dan disimpan pada suhu $4{ }^{\circ} \mathrm{C}$. Serbuk tersebut kemudian diukur kadar airnya (AOAC, 2005).

\section{Persiapan Sampel \\ Preparasi Sampel Ekstrak}

Aktivitas antioksidan bubuk sari buah pamelo diukur, diawali dengan ekstraksi bubuk untuk merilis senyawa metabolit sekunder yang terenkapsulasi oleh bahan penyalut. Preparasi sampel ekstrak merujuk pada metode Agudelo et al., (2017) yang dimodifikasi. Bubuk sari buah jeruk pamelo (10 g) diekstraksi dengan $100 \mathrm{ml}$ metanol/air (80:20, v/v) dan dimaserasi selama 1 jam pada suhu ruang. Sampel disaring menggunakan kertas Whatman menggunakan filter vakum (Yamato Scientific), dan residu diekstraksi kembali. Ekstrak digabungkan, dan metanol diuapkan pada suhu $45{ }^{\circ} \mathrm{C}$ menggunakan vakum rotary evaporator. Sampel ekstrak pekat kemudian digunakan dalam analisis DPPH, total fenolik, total flavonoid, inhibisi lipase pankrease dan inhibisi kolesterol esterase.

\section{Pengukuran aktivitas antioksidan Kapasitas Antioksidan Metode DPPH}

Ekstrak $100 \mu \mathrm{l}(10 \mathrm{mg} / \mathrm{ml})$ ditambah larutan DPPH $100 \mu \mathrm{l} \quad(0,2 \mathrm{mM}$ dalam metanol) dan diinkubasi selama 30 menit pada suhu ruang pada kondisi gelap. Penurunan absorbansi diukur pada $515 \mathrm{~nm}$. DPPH scavenging activity dihitung menggunakan kurva standar asam askorbat dan dinyatakan dalam AEAC (Ascorbic Acid Equivalent Antioxidant Capacity) (mg AEAC/100 g bubuk) (Mäkynen et al., 2013).

Tabel 1. Formula pembubukan sari buah C. maxima kultivar Nambangan

\begin{tabular}{cccc}
\hline \multirow{2}{*}{ No. } & \multirow{2}{*}{ Formulasi } & \multicolumn{2}{c}{ Coating agents and ratios } \\
\cline { 3 - 4 } & & Maltodextrin $(\mathrm{MD}) \mathrm{DE}_{12}(\%)$ & Gum Arabic $(\mathrm{GA})(\%)$ \\
\hline 1 & $10: 0 \mathrm{MD} \mathrm{DE}_{12} / \mathrm{GA}$ & 90 & 0 \\
2 & $9: 1 \mathrm{MD} \mathrm{DE}_{12} / \mathrm{GA}$ & 80 & 10 \\
3 & $8: 2 \mathrm{MD} \mathrm{DE}_{12} / \mathrm{GA}$ & 70 & 20 \\
4 & $7: 3 \mathrm{MD} \mathrm{DE}_{12} / \mathrm{GA}$ & & 30 \\
\hline
\end{tabular}




\section{Kandungan asam askorbat}

Analisis asam askorbat mengacu pada Eder (2004). Sebanyak 2,5 g bubuk sari buah pamelo ditambahkan $5 \mathrm{ml}$ larutan $\mathrm{HPO}_{3} \quad 2 \%$ dan disaring dengan kertas Whatman No. 42, larutan sampel ditambahkan $\mathrm{HPO}_{3} 2 \%$ hingga volume 25 $\mathrm{ml}$. Konsentrasi seri larutan asam askorbat $(0,0,05,0,1,0,15,0,2,0,25$, dan 0,3 ml) diencerkan dengan $\mathrm{HPO}_{3}$ 2\% hingga volume $2,5 \mathrm{ml}$. Larutan pewarna DCIP $5 \mathrm{ml}$ ditambahkan ke dalam 2,5 $\mathrm{ml}$ standar atau sampel. Absorbansi diukur pada $518 \mathrm{~nm}$ dan harus dilakukan dalam 15-20 detik setelah larutan dye ditambahkan. Perhitungan konsentrasi asam askorbat berdasarkan persamaan (1).

$$
\mathrm{AA}(\mathrm{mg} / 100 \mathrm{~g})=\frac{(\mathrm{c} \times \mathrm{vt} \times 100)}{(\mathrm{v} \times \mathrm{w})} \times \mathrm{FP} \ldots
$$

Dimana, AA = konsentrai asam askorbat; c $=$ konsentrasi asam askorbat dari kurva standar (mg); vt = volume ekstrak total $(\mathrm{ml}) ; \mathrm{v}=$ volume ekstrak yang dianalisis $(\mathrm{ml}) ; \mathrm{w}=$ berat $(\mathrm{g})$; dan $\mathrm{FP}=$ faktor pengenceran.

\section{Kandungan Total Fenolik}

Pengukuran kandungan total fenolik mengacu pada (Malik dan Ahmad, 2015) dengan sedikit modifikasi. Ekstrak yang dilarutkan dalam metanol $80 \%$ diambil sebanyak $20 \mu \mathrm{l} \quad(1 \mathrm{mg} / \mathrm{ml})$ dicampur dengan $8 \mu \mathrm{l}$ reagen Folin Ciocalteu (sebelumnya diencerkan 10 kali lipat). Setelah 4 menit ditambahkan $80 \mu \mathrm{l} \mathrm{Na} \mathrm{N}_{2} \mathrm{CO}_{3}$ 7\% dan akuades sampai $200 \mu \mathrm{l}$, kemudian diinkubasi selama 1 jam di ruangan gelap. Absorbansi diukur pada 750 nm (iMarkTM, Bio-Rad). Total fenol ditentukan menggunakan kurva standar asam galat (10-50 ppm) dan dinyatakan sebagai mg ekuivalen asam galat (mg GAE/100 g bubuk).

\section{Kandungan Total Flavonoid}

Pengukuran kandungan total fenolik mengacu pada Ahmad et al. (2015) dengan sedikit modifikasi. Ekstrak pekat yang dilarutkan dalam metanol $80 \%$ diambil sebanyak $50 \mu \mathrm{l}(10 \mathrm{mg} / \mathrm{ml})$ dan dicampur dengan $100 \mu \mathrm{l}$ metanol 80\%, $10 \mu \mathrm{l} \mathrm{AlCl}_{3}$
$10 \%, 10 \mu \mathrm{l} 1 \mathrm{M} \mathrm{CH}_{3} \mathrm{COOK}$, dan akuades hingga $200 \mu 1$, kemudian diinkubasi selama 30 menit di ruangan gelap. Absorbansi diukur pada $415 \mathrm{~nm}$. Total flavonoid ditentukan menggunakan kurva standar quercetin (10-50 ppm) dan dinyatakan sebagai $\mathrm{mg}$ ekuivalen quercetin (mg QE/100 g bubuk).

\section{Analisis potensi hipolipidemik in vitro Inhibisi lipase pankreas}

Inhibisi lipase pankreas mengacu pada Chedda et al. (2016) dengan sedikit modifikasi. Sebanyak $6 \mathrm{mg}$ lipase pankreas dilarutkan dalam $10 \mathrm{~mL}$ larutan buffer (PBS dan 0,5\% (v/v) Triton-X-100, pH 7,2). Pengujian dilakukan dengan menginkubasi ekstrak $25 \mu \mathrm{l}$ atau kontrol positif, lipase pankreas $50 \mu \mathrm{l}$, larutan buffer $100 \mu \mathrm{l}$, dan 25 $\mu 15 \mathrm{mM}$ p-NPB pada suhu $37{ }^{\circ} \mathrm{C}$ selama 30 menit, dan absorbansi diukur pada $415 \mathrm{~nm}$. Ekstrak pekat dilarutkan dalam PBS dan dibuat rangkaian kosentrasi ekstrak sebesar 250, 125, 62,5, 31,25, dan 15,625 $\mu \mathrm{g} / \mathrm{ml}$. Sedangkan rangkaian konsentrasi kontrol positif (orlistat) yang digunakan adalah 25, $12,5,6,25,3,125$, dan $1,5625 \mu \mathrm{g} / \mathrm{ml}$.

\section{Inhibisi kolesterol esterase}

Inhibisi kolesterol esterase mengacu pada Mäkynen et al. (2013). Sebanyak $5 \mu \mathrm{l}$ ekstrak ditambah $50 \mu 12 \mathrm{mM}$ taurocholic acid, $5 \mu 120 \mathrm{mM}$ p-NPB, dan $30 \mu \mathrm{l}$ PBS (pH 6.9). Reaksi dimulai dengan menambahkan $10 \mu \mathrm{l}$ kolesterol esterase pankreas yang dilarutkan dalam PBS (1 $\mu \mathrm{g} / \mathrm{ml})$. Campuran larutan selama 5 menit diinkubasi pada suhu $25^{\circ} \mathrm{C}$, dan absorbansi diukur pada $415 \mathrm{~nm}$. Uji inhibisi esterase kolesterol menggunakan seri konsentrasi ekstrak 62,5, 125, 250, 500, dan 1000 \%g/ml. Pada rangkaian konsentrasi kontrol positif (simvastatin) yang digunakan adalah 3,125, 6,25, 12,5, 25, $50 \mu \mathrm{g} / \mathrm{ml}$.

Penghambatan enzim (lipase pankreas dan kolesterol esterase) dihitung dengan rumus pada Persamaan (2).

$$
\operatorname{PE}(\%)=\frac{((\mathrm{AB}-\mathrm{AKB})-(\mathrm{AS}-\mathrm{AKS}))}{(\mathrm{AB}-\mathrm{AKB})} \times 100 \% \ldots
$$

Dimana, $\mathrm{PE}=$ penghambatan enzim; $\mathrm{AB}=$ absorbansi blanko; $\mathrm{AKB}=$ absorbansi 
kontrol blanko (tanpa enzim); AS = absorbansi sampel; dan AKS = absorbansi kontrol sampel (tanpa enzim).

Nilai konsentrasi ekstrak bubuk dan rerata persen penghambatan (\%) dari 3 ulangan diplot pada sumbu $x$ dan $y$ pada persamaan regresi linear, yaitu Persamaan (3).

$y=a+b x$

Persamaan (3) digunakan untuk mencari nilai $\mathrm{IC}_{50}$ (inhibitor concentration $50 \%$ ) dari masing-masing sampel dengan menyatakan nilai $y$ sebesar 50 dan nilai $x$ akan diperoleh dari perhitungan $\mathrm{IC}_{50}$. Nilai $\mathrm{IC}_{50}$ menyatakan besarnya konsentrasi larutan sampel yang dibutuhkan untuk menghambat enzim (lipase pankreas dan kolesterol esterase) sebesar $50 \%$.

\section{Analisis Data}

Data uji dianalisis dengan analisis varians (ANOVA) menggunakan SPSS versi 22 (SPSS Inc., Chicago, IL, USA). Jika terdapat perbedaan signifikan maka dilanjutkan dengan uji Duncan (DMRT) ( $p$ $<0,05)$.

\section{HASIL DAN PEMBAHASAN}

Kadar air, kapasitas antioksidan, fenolik, flavonoid dan asam askorbat dari bubuk sari buah pamelo

Kadar air merupakan karakteristik yang berkaitan dengan efisiensi pengeringan (Cynthia et al., 2015). Kadar air bubuk bervariasi antara 5,27-5,86\% (Tabel 2). Hasil penelitian menunjukkan bahwa semakin tinggi konsentrasi GA, maka kadar air juga akan meningkat. Penelitian Du et al. (2014) menunjukkan bahwa bubuk buah yang dienkapsulasi gum arab memiliki kadar air yang lebih tinggi dibandingkan dengan bubuk yang dienkapsulasi maltodekstrin. Hasil ini berbeda dengan Cynthia et al. (2015), dimana maltodekstrin menghasilkan kadar air yang lebih tinggi dibandingkan bubuk dengan gum arab atau campuran gum arab/maltodextrin. Perbedaan hasil tersebut dapat disebabkan oleh perbedaan DE maltodekstrin, komposisi gum arab, kondisi proses, dan interaksi bahan utama dan bahan penyalut (Tontul dan Topuz, 2017). Dextrose equivalent (DE) berkisar antara 3 sampai 20 dan menunjukkan tingkat hidrolisis pati, dimana semakin tinggi nilai DE meningkatkan kadar hidrolisis maltodekstrin, sehingga meningkatkan kadar air produk (Campelo et al., 2017).

Senyawa fenol dan aktivitas antioksidan dalam pangan dapat dipengaruhi oleh proses pasca panen seperti penyimpanan, pengemasan, dan fermentasi (Shofian et al., 2011). Enkapsulasi dapat digunakan untuk melindungi komponen pangan yang sensiti selama penyimpanan, menutupi atau mempertahankan aroma dan rasa di dalamnya termasuk off-flavour, rasa pahit dan asam dari polifenol (Ballesteros et al., 2017). Berbagai faktor yang mempengaruhi proses pengeringan semprot seperti suhu, laju alir pengeringan, kecepatan atomisasi, bahan penyalut, dan konsentrasinya serta interaksi antara bahan penyalut dan bahan aktif harus diperhatikan (Ozkan et al., 2019).

Pemilihan bahan penyalut yang tepat berguna untuk melindungi komponen fungsional dan kapasitas antioksidan produk akhir (Fang dan Bhandari, 2012). Parameter yang digunakan untuk mengetahui pengaruh formulasi antara lain kapasitas antioksidan, kadar total fenol, kadar total flavonoid, dan kadar asam askorbat dari bubuk sari buah pamelo yang ditunjukkan pada Tabel 2. Kapasitas antioksidan diukur menggunakan uji DPPH. Kapasitas antioksidan keempat formulasi menunjukkan perbedaan yang signifikan satu sama lain, dimana semakin tinggi GA yang ditambahkan, semakin tinggi kapasitas antioksidan. Hasil pengukuran total kapasitas antioksidan menunjukkan adanya beda nyata akibat perbedaan perlakuan rasio penambahan GA, dimana semakin tinggi GA yang ditambahkan, nilai total kapasitas antioksidan semakin besar. 
Tabel 2. Perbandingan kadar air, kapasitas antioksidan, total fenolik, total flavonoid dan asam askorbat bubuk sari buah pamelo Nambangan

\begin{tabular}{cccccc}
\hline Formulasi & $\begin{array}{c}\text { Kadar Air } \\
(\%)\end{array}$ & $\begin{array}{c}\text { Kapasitas } \\
\text { Antioksidan } \\
(\mathrm{mg} \mathrm{AEAC/100} \mathrm{g)}\end{array}$ & $\begin{array}{c}\text { Total Fenolik } \\
(\mathrm{mg} \mathrm{AG} / 100 \mathrm{~g})\end{array}$ & $\begin{array}{c}\text { Total } \\
\text { Flavonoid } \\
(\mathrm{mg} \mathrm{QE} / 100 \mathrm{~g})\end{array}$ & $\begin{array}{c}\text { Asam Askorbat } \\
(\mathrm{mg} \text { AA/100 g) }\end{array}$ \\
\hline 10:0 MD/GA & $5,01 \pm 0,03^{\mathrm{a}}$ & $683,76 \pm 5,2^{\mathrm{a}}$ & $322,11 \pm 2,42^{\mathrm{a}}$ & $133,69 \pm 5,15^{\mathrm{a}}$ & $342,64 \pm 18,05^{\mathrm{a}}$ \\
9:1 MD/GA & $5,36 \pm 0,01^{\mathrm{b}}$ & $700,70 \pm 7,15^{\mathrm{b}}$ & $362,60 \pm 5,29 \mathrm{~b}$ & $169,47 \pm 6,90^{\mathrm{b}}$ & $370,67 \pm 8,87 \mathrm{bc}$ \\
8:2 MD/GA & $5,51 \pm 0,04^{\mathrm{b}}$ & $713,51 \pm 6,50^{\mathrm{c}}$ & $396,80 \pm 8,34^{\mathrm{c}}$ & $184,00 \pm 4,39 \mathrm{c}$ & $395,84 \pm 15,14^{\mathrm{bc}}$ \\
7:3 MD/GA & $5,86 \pm 0,15^{\mathrm{c}}$ & $730,43 \pm 4,95^{\mathrm{d}}$ & $433,98 \pm 8,16^{\mathrm{d}}$ & $236,76 \pm 4,84^{\mathrm{d}}$ & $413,30 \pm 13,02^{\mathrm{c}}$ \\
\hline
\end{tabular}

Notasi superscript yang sama pada kolom yang sama menunjukkan tidak beda nyata $(a=5 \%)$. AEAC (Ascorbic Acid Equivalent Antioxidant Capacity), AA (asam askorbat), GAE (gallic acid equivalent), $\mathrm{QE}$ (quercetin equivalent).

Penelitian Tolun et al. (2016) menunjukkan hasil serupa dimana aktivitas antioksidan dari bubuk mikrokapsul ekstrak polifenol anggur (1:1 bahan utama/bahan penyalut; 8:2 MD 4-7 DE/GA; dan suhu pengeringan antara 120$180^{\circ} \mathrm{C}$ ) lebih tinggi dibandingkan aktivitas antioksidan dari bubuk MD 4-7 DE/GA 10:0.

Kombinasi MD/GA memberikan perlindungan yang lebih baik untuk mempertahankan kandungan asam askorbat dibandingkan dengan penambahan MD saja. Analisis statistik kandungan asam askorbat tidak menunjukkan perbedaan yang signifikan antara bubuk MD/GA 9:1 dan 8:2 serta bubuk MD/GA 8:2 dan 7:3, masih dapat dilihat bahwa bubuk 7: 3 MD/GA memiliki asam askorbat tertinggi, sedangkan tanpa penambahan GA (10:0 MD/GA) menghasilkan kadar asam askorbat terendah. Righetto dan Netto (2006) mengenkapsulasi asam askorbat sari buah ceri dari India Barat menggunakan maltodekstrin DE20 dan campuran maltodekstrin/gum arab. Selama sembilan bulan penyimpanan pada suhu 15, 25, 35, dan $45^{\circ} \mathrm{C}$, bubuk campuran MD/GA (3:1) dapat melindungi asam askorbat lebih baik daripada MD DE20.

Berdasar hasil pengukuran total fenolik terlihat bahwa semakin besar rasio GA yang ditambahkan, kandungan total fenolik bubuk semakin tinggi (Tabel 2). Hasil ini didukung oleh penelitian Tan et al. (2015) pada bubuk mikroenkapsulasi pare dimana bubuk dengan rasio bahan penyalut 1:1, 3:2, 7:3, dan 4:1 MD/GA menghasilkan total fenolik lebih tinggi dibandingkan bubuk 1:0 MD/GA. Pada penelitian Tolun et al. (2016) diperoleh hasil bahwa bubuk ekstrak polifenol anggur dengan bahan penyalut campuran MD dan GA menghasilkan total fenol lebih tinggi dibandingkan bubuk dengan MD saja.

Hasil pengukuran total flavonoid menunjukkan bahwa total flavonoid meningkat, seiring peningkatan rasio GA yang ditambahkan. Bubuk 7:3 MD/GA memiliki total flavonoid tertinggi dan bubuk 10:0 MD/GA memiliki total flavonoid terendah (Tabel 2). Hasil penelitian Diaz et al. (2015) terhadap pengaruh pembedaan bahan penyalut (maltodekstrin, gum arab, dan whey protein concentrate) terhadap bubuk mikrokapsul sari buah blackberry menunjukkan bahwa aktivitas antioksidan dan total flavonoid tertinggi dihasilkan oleh bubuk dengan penyalut gum arab diikuti oleh maltodekstrin dan whey protein concentrate.

Ekstrak metanol air dari bubuk sari buah pamelo dengan perlakuan 7:3 MD/GA memiliki kapasitas antioksidan, kandungan total fenol, total flavonoid, dan kadar vitamin $C$ tertinggi dibandingkan bubuk perlakuan lainnya. Hasil ini dapat dikarenakan penambahan gum arab meningkatkan stabilitas komponen bioaktif terhadap panas dari proses pengeringan. Gum arab memiliki kemampuan untuk membentuk struktur matriks yang baik dengan maltodekstrin guna membentuk penghalang (barrier) antara komponen fenolik dan flavonoid terhadap panas. Campuran gum arab dan maltodekstrin sebagai bahan penyalut memberikan perlindungan yang lebih baik daripada 
Jurnal Teknologi Pertanian Vol. 22 No. 3 [Desember 2021] 149-160

Kapasitas Antioksidan serta Inhibisi Lipase dan Kolesterol Esterase dari BubukSari Buah Pamelo [Pawestri dkk]

perlindungan yang diberikan oleh maltodekstrin saja dikarenakan gum arab memiliki kemampuan emulsifikasi dan

karakteristik pembentuk film yang baik (Tolun et al., 2016).

Tabel 3. Nilai $\mathrm{IC}_{50}$ ekstrak bubuk C.maxima terhadap lipase pankreatik dan kolesterol esterase

\begin{tabular}{ccc}
\hline Perlakuan & \multicolumn{2}{c}{ Nilai IC $_{50}(\mu \mathrm{g} / \mathrm{ml})$} \\
\cline { 2 - 3 } & Lipase Pankreatik & Kolesterol esterase \\
\hline 10:0 MD/GA & 308,40 & 1352,05 \\
9:1 MD/GA & 272,88 & 1172,80 \\
8:2 MD/GA & 242,18 & 1075,30 \\
7:3 MD/GA & 211,42 & 934,19 \\
Orlistat & $0,22^{*}$ & \\
Simvastatin & - & 30,50 \\
\hline
\end{tabular}

*Zhang et al. (2008)

\section{Penghambatan lipase pankreas dan kolesterol esterase}

Hasil pada Tabel 3 menunjukkan nilai $\mathrm{IC}_{50}$ dari keempat ekstrak metanol terhadap lipase pankreas dan kolesterol esterase. Nilai $\mathrm{IC}_{50}$ ekstrak metanol terhadap lipase pankreas berkisar antara 211,42 - 308,40 $\mathrm{\mu g} / \mathrm{ml}$. Sedangkan, nilai $\mathrm{IC}_{50}$ ekstrak metanol terhadap kolesterol esterase berkisar antara 934,19-1352,05 $\mu \mathrm{g} / \mathrm{ml}$, dan nilai $\mathrm{IC}_{50}$ simvastatin adalah $30,50 \mu \mathrm{g} / \mathrm{ml}$. Nilai $\mathrm{IC}_{50}$ ekstrak bubuk MD/GA 7:3 terendah dibandingkan dengan $\mathrm{IC}_{50}$ ekstrak bubuk lainnya.

Polifenol dianggap sebagai metabolit sekunder yang bertanggungjawab dalam menghambat aktivitas lipase pankreas. Lunagariya et al. (2014) mengemukakan bahwa adanya sisi polivalen pada polifenol menyebabkan polifenol dapat berikatan dengan lipase pankreas, sehingga menghambat aktivitasnya. Kemampuan flavonoid dalam menghambat lipase pankreas dapat disebabkan oleh adanya hidroksil fenolik dalam strukturnya. Penelitian pada metabolit sekunder menunjukkan bahwa senyawa fenolik berpotensi menghambat aktivitas kolesterol esterase, tetapi bagaimana mekanisme penghambatan kolesterol esterase oleh senyawa fenolik dan flavonoid masih belum diketahui (Ngamukote et al., 2011).

Ekstrak bubuk MD/GA 7:3 menghasilkan penghambatan lipase pankreas dan kolesterol esterase tertinggi dibandingkan ekstrak lainnya. Hal ini dapat disebabkan karena enkapsulasi dengan rasio gum arab semakin tinggi memberikan perlindungan terhadap bahan aktif yang lebih baik terhadap suhu tinggi yang digunakan selama proses pengeringan semprot dibandingkan dengan rasio gum arab lebih rendah. Campuran gum arab dan maltodekstrin membentuk pelindung (barrier) yang mengenkapsulasi komponen bioaktif yang melindunginya terhadap panas atau suhu tinggi (Tolun et al., 2016).

\section{SIMPULAN}

Ekstrak metanol air dari bubuk 7:3 MD/GA memiliki kapasitas antioksidan, kandungan total fenolik, total flavonoid dan vitamin $C$ tertinggi dibandingkan bubuk spray dried perlakuan lainnya. Nilai $\mathrm{IC}_{50}$ bubuk sari buah jeruk pamelo berkisar antara 211,42-308,40 $\mu \mathrm{g} / \mathrm{ml}$ terhadap lipase pankreatik dan $\mathrm{IC}_{50}$ 934,19-1352,05 $\mu \mathrm{g} / \mathrm{ml}$ terhadap kolesterol esterase dimana $\mathrm{IC}_{50}$ terendah dihasilkan oleh ekstrak sari buah jeruk pamelo dari bubuk 7:3 MD/GA. Aktivitas inhibisi ekstrak metanol air (80:20) bubuk sari buah jeruk pamelo lebih besar terhadap lipase dibandingkan dengan kolesterol esterase. 


\section{DAFTAR PUSTAKA}

Agudelo, -C., Barros, -L., Santos-Buelga, -C., Martínez-Navarrete, -N., Ferreira, I, C, F, -R., 2017. Phytochemical content and antioxidant activity of grapefruit (Star Ruby): A comparison between fresh freeze-dried fruits and different powder formulations. LWT - Food Science and Technology. 80, 106-112. https://doi.org/10.1016/j.lwt.2017.0 2.006

Ahmad, A, -R., Juwita, -J., Ratulangi, S, A, -D., 2015. Penetapan kadar fenolik dan flavonoid total ekstrak metanol buah dan daun patikala (Etlingera elatior (Jack) R.M.SM). Pharmaceutical Science $\mathcal{E} \quad$ Research. 2, 1-10. https://doi.org/10.7454/psr.v2i1.34 81

Al-Ismail, -K., El-Dijani, -L., Al-Khatib, -H., Saleh, -M., 2016. Effect of microencapsulation of vitamin C with gum arabic, whey protein isolate and some blends on its stability. Journal of Scientific and Industrial Research. (India). 75, 176180.

Angel, R, C, -M., Espinosa-Muñoz, L, -C., Aviles-Aviles, -C., González-García, R., Moscosa-Santillán, -M., GrajalesLagunes, -A., Abud-Archila, -M., 2009. Spray-drying of passion fruit juice using lactose- maltodextrin blends as the support material. Brazilian Archives of Biology and Technology. 52, 1011-1018. https:// doi.org/10.1590/S151689132009000400026

AOAC, 2005. Official Methods of Analysis of AOAC International, 18th ed. AOAC International, Gaithersburg.

Atefi, -M., Mohammadi, -A., Nayebzadeh, K., 2017. Using B-cyclodextrin and Arabic gum as wall materials for encapsulation of Saffron essential oil (winter2017). Iranian Journal of Pharmaceutical Research. 16, 93-102.

Ballesteros, L, -F., Ramirez, M, -J., Orrego, C, E., Teixeira, J, -A., Mussatto, S, -I., 2017. Encapsulation of antioxidant phenolic compounds extracted from spent coffee grounds by freeze- drying and spray-drying using different coating materials. Food Chemistry. 237, 623-631. https://doi.org/10.1016/j.foodchem. 2017.05.142

Betz, -M., Kulozik, -U., 2011. Microencapsulation of bioactive bilberry anthocyanins by means of whey protein gels. Procedia Food Science. $\quad 1$, 2047-2056. https://doi.org/10.1016/j.profoo.201 1.10 .006

Botrel, D, -A., Borges, S, -V., Fernandes, R, V, de B., Viana, A, -D., da Costa, J, M, G., Marques, G, -R., 2012. Evaluation of spray drying conditions on properties of microencapsulated oregano essential oil. International Journal of Food Science \& Technology. 47 , 1-8.

https://doi.org/10.1111/j.13652621.2012.03100.x

Campelo, P, -H., do Carmo, E, -L., Zacarias, R, -D., Yoshida, M, -I., Ferraz, V, -P., de Barros Fernandes, R, -V., Botrel, D, -A., Borges, S, -V., 2017. Effect of dextrose equivalent on physical and chemical properties of lime essential oil microparticles. Industrial Crops and Products. 102, 105-114. https://doi.org/10.1016/j.indcrop.20 17.03.021

Chedda, -U., Kaikini, -A., Bagle, -S., Seervi, M., 2016. In vitro pancreatic lipase inhibition potential of commonly used Indian spices. IOSR Journal Of Pharmacy. 6, 10-13.

Chen, -J., Li, -S., Xu, -J., Ding, -F., Wang, -Z., Cheng, -Y., Deng, -X., 2015. Concentration and distribution of main bitter compounds in fruit tissues of "Oroblanco" (Citrus grandis L.×Citrus paradisi Macf.). Scientia Horticulturae. 193, 84-89. https://doi.org/10.1016/j.scienta.201 5.05 .034

Cynthia, S, -J., Don Bosco, -J., Bhol, -S., 2015. Physical and structural properties of spray dried tamarind (Tamarindus indica L.) pulp extract powder with encapsulating hydrocolloids. International Journal of Food Properties. 18 , 1793-1800. 
Jurnal Teknologi Pertanian Vol. 22 No. 3 [Desember 2021] 149-160

Kapasitas Antioksidan serta Inhibisi Lipase dan Kolesterol Esterase dari BubukSari Buah Pamelo [Pawestri dkk]

https:/ / doi.org/10.1080/10942912.2 014.940536

Di Battista, C, -A., Constenla, -D., RamírezRigo, M, -V., Piña, -J., 2015. The use of Arabic gum, maltodextrin and surfactants in the microencapsulation of phytosterols by spray drying. Powder Technology. 286, 193-201. https://doi.org/10.1016/j.powtec.20 15.08.016

Diaz, D, -I., Beristain, C, -I., Azuara, -E., Luna, -G., Jimenez, -M., 2015. Effect of wall material on the antioxidant activity and physicochemical properties of Rubus fruticosus juice microcapsules. Journal of Microencapsulation. 32, 247-254. https://doi.org/10.3109/02652048. 2015.1010458

Du, -J., Ge, Z, -Z., Xu, -Z., Zou, -B., Zhang, -Y., Li, C, -M., 2014. Comparison of the efficiency of five different drying carriers on the spray drying of persimmon pulp powders. Drying Technology. 32, 1157-1166. https://doi.org/10.1080/07373937.2 014.886259

Eder, R., 2004. Pigments, in: Nollet, L.M.L. (Ed.), Handbook of Food Analysis. Marcell Dekker Inc., New York. https://doi.org/10.5860/choice.1944 12

Fang, -Z., Bhandari, -B., 2012. Comparing the efficiency of protein and maltodextrin on spray drying of bayberry juice. Food Research International. 48, 478-483. https://doi.org/10.1016/j.foodres.20 12.05.025

Fernandes, R, V, D, -B., Borges, S, -V., Botrel, D, -A., 2014. Gum arabic/starch/maltodextrin/inulin as wall materials on the microencapsulation of rosemary essential oil. Carbohydrate Polymers. 101, 524-532. https://doi.org/10.1016/j.carbpol.2013.0 9.083

Garofulic, I, -E., Zoric, -Z., Pedisic, -S., Dragovic-Uzelac, -V., 2016. Optimization of sour cherry juice spray drying as affected by carrier material and temperature. Food

\author{
Technology Biotechnology. \\ https://doi.org/10.17113/ft \\ b.54.04.16.4601
}

Kawaii, -S., Tomono, -Y., Katase, -E., Ogawa, K., Yano, -M., 1999. HL-60 differentiating activity and flavonoid content of the readily extractable fraction prepared from Citrus juices. Journal of Agricultural and Food Chemistry. $\quad 47$, 128-135. https://doi.org/10.1021/jf9805101

Kha, T, -C., Nguyen, M, -H., Roach, P, -D., 2010. Effects of spray drying conditions on the physicochemical and antioxidant properties of the Gac (Momordica cochinchinensis) fruit aril powder. Journal of Food Engineering. 98, 385-392. https://doi.org/10.1016/j.jfoodeng.2 010.01 .016

Krishnan, -S., Kshirsagar, A, -C., Singhal, R, S., 2005. The use of gum arabic and modified starch in the microencapsulation of a food flavoring agent. Carbohydrate Polymers. 62, 309-315. https://doi.org/10.1016/j.carbpol.20 05.03.020

Lunagariya, N, -A., Patel, N, -K., Jagtap, S, C., Bhutani, K, -K., 2014. Inhibitors of pancreatic lipase: state of the art and clinical perspectives. EXCLI Journal. 13, 897-921.

Mäkynen, -K., Jitsaardkul, -S., Tachasamran, P., Sakai, -N., Puranachoti, -S., Nirojsinlapachai, -N., Chattapat, -V., Caengprasath, -N., Ngamukote, -S., Adisakwattana, -S., 2013. Cultivar variations in antioxidant and antihyperlipidemic properties of pomelo pulp (Citrus grandis [L.] Osbeck) in Thailand. Food Chemistry. 139, 735-743. https:/ / doi.org/10.1016/j.foodchem. 2013.02.017

Malik, -A., Ahmad, A, -R., 2015. Determination of phenolic and flavonoid contents of ethanolic extract of Kanunang leaves (Cordia myxa L.). International Journal of PharmTech Research. 7, 243-246. 
Mishra, -P., Mishra, -S., Mahanta, C, -L., 2014. Effect of maltodextrin concentration and inlet temperature during spray drying on physicochemical and antioxidant properties of amla (Emblica officinalis) juice powder. Food and Bioproducts Processing. 92, 252-258. https:/ / doi.org/10.1016/j.fbp.2013. 08.003

Muzaffar, -K., Dinkarrao, B, -V., Kumar, -P., 2016. Optimization of spray drying conditions for production of quality pomegranate juice powder. Cogent Food And Agriculture. 2, 1-9. https://doi.org/10.1080/23311932.2 015.1127583

Ngamukote, -S., Mäkynen, -K., Thilawech, T., Adisakwattana, -S., 2011. Cholesterol-lowering activity of the major polyphenols in grape seed. Molecules. 16, 5054-5061. https://doi.org/10.3390/molecules1 6065054

Oboh, -G., Bello, F, -O., Ademosun, A, -O., 2014.

Hypocholesterolemic properties of grapefruit (Citrus paradisii) and shaddock (Citrus maxima) juices and inhibition of angiotensin-1-converting enzyme activity. Journal of Food and Drug Analysis. 22, 477-484. https://doi.org/10.1016/j.jfda.2014.0 6.005

Ozkan, -G., Franco, -P., De Marco, -I., Xiao, -J., Capanoglu, -E., 2019. A review of microencapsulation methods for food antioxidants: Principles, advantages, drawbacks and applications. Food Chemistry. 272, 494-506.

https://doi.org/10.1016/j.foodchem. 2018.07.205

Palma-Rodrígueza, H, -M., AlvarezRamírezb, -J., Vargas-Torres, -A., 2018. Using modified starch/maltodextrin microparticles for enhancing the shelf life of ascorbic acid by the spray-drying method. Starch. 70, 1700323. https://doi.org/10.1002/star.201700 323
Pitalua, -E., Jimenez, -M., Vernon-Carter, E, J., Beristain, C, -I., 2010. Antioxidative activity of microcapsules with beetroot juice using gum Arabic as wall material. Food and Bioproducts Processing. 88, 253-258. https://doi.org/10.1016/j.fbp.2010.0 1.002

Pu, -P., Gao, D, -M., Mohamed, -S., Chen, -J., Zhang, -J., Zhou, X, -Y., Zhou, N, -J., Xie, -J., Jiang, -H., 2012. Naringin ameliorates metabolic syndrome by activating AMP-activated protein kinase in mice fed a high-fat diet. Archives of Biochemistry and Biophysics. 518, 61-70. https://doi.org/10.1016/j.abb.2011.1 1.026

Ravichandran, -K., Palaniraj, -R., Saw, N, M, M, -T., Gabr, A, M, -M., Ahmed, A, -R., Knorr, -D., Smetanska, -I., 2014. Effects of different encapsulation agents and drying process on stability of betalains extract. Journal of Food Science and Technology. 51, 2216-2221. https://doi.org/10.1007/s13197012-0728-6

Righetto, A, -M., Netto, F, -M., 2006. Vitamin C stability in encapsulated green West Indian cherry juice and in encapsulated synthetic ascorbic acid. Jounal Science Food and Agriculture. 86, 1202-1208. https://doi.org/10.1002/jsfa.2469

Rocha, G, -A., Fávaro-Trindade, C, -S., Grosso, C, R, -F., 2012. Microencapsulation of lycopene by spray drying: Characterization, stability and application of microcapsules. Food and Bioproducts Processing. 90, 37-42. https://doi.org/10.1016/j.fbp.2011.01 .001

Shofian, N, -M., Hamid, A, -A., Osman, -A., Saari, -N., Anwar, -F., Dek, M,S, -P., Hairuddin, M, -R., 2011. Effect of freeze-drying on the antioxidant compounds and antioxidant activity of selected tropical fruits. International Journal of Molecular Science. 12, 4678-4692. https://doi.org/10.3390/ijms12074 678 
Susanto, -S., 2004. Changes in fruit quality of pummelo experiencing storage and remaining on the tree (in Indonesian). Hayati. 11, 25-28.

Tan, S, -P., Kha, T, -C., Parks, -S., Stathopoulos, -C., Roach, P., -D., 2015. Optimising the encapsulation of an aqueous bitter melon extract by spray-drying. Foods. 4, 400-419. https://doi.org/10.3390/foods4030400

Tolun, -A., Altintas, -Z., Artik, -N., 2016. Microencapsulation of grape polyphenols using maltodextrin and gum arabic as two alternative coating materials: Development and characterization. Journal Biotechnology. 239, 23-33. https://doi.org/10.1016/j.jbiotec.2 016.10.001

Tripoli, -E., Guardia, M. -La., Giammanco, -S., Majo, D. -Di., Giammanco, -M., 2007. Citrus flavonoids: Molecular structure, biological activity and nutritional properties: A review. Food Chemistry. 104, 466-479. https://doi.org/10.1016/j.foodchem. 2006.11.054

Xu, -G., Liu, -D., Chen, -J., Ye, -X., Ma, -Y., Shi, -J., 2008. Juice components and antioxidant capacity of citrus varieties cultivated in China. Food Chemistry. 106, 545-551. https://doi.org/10.1016/j.foodche m.2007.06.046
Yousefi, -S., Emam-Djomeh, -Z., Mousavi, S, M., 2011. Effect of carrier type and spray drying on the physicochemical properties of powdered and reconstituted pomegranate juice (Punica Granatum L.). Journal Food Science and Technology. 48, 677-684. https://doi.org/10.1007/s13197-0100195-x

Zhang, -J., Kang, M, -J., Kim, M, -J., Kim, M, E., Song, J, -H., Lee, Y, -M., Kim, J, -I., 2008. Pancreatic lipase inhibitory activity of taraxacum officinale in vitro and in vivo. Nutrition Research and Practice. 2, 200-203. https://doi.org/10.4162/nrp.2008.2. 4.200

Zhang, -L., Mou, -D., Du, -Y., 2007. Procyanidins: Extraction and microencapsulation. Journal Science Food and Agriculture. 87, 2192-2197. https://doi.org/10.1002/jsfa.2899

Zhang, -M., Duan, -C., Zang, -Y., Huang, -Z., Liu, -G., 2011. The flavonoid composition of flavedo and juice from the pummelo cultivar (Citrus grandis (L.) Osbeck) and the grapefruit cultivar (Citrus paradisi) from China. Food Chemistry. 129, 1530-1536. https://doi.org/10.1016/j.foodchem. 2011.05.136 